\title{
L'ús del misteri per a potenciar el treball actiu de l'expressió oral i escrita
}

\author{
Andrea Cuenca Piqueras \\ IES Las Lagunas, Torrevieja \\ andreacupi24@gmail.com
}

Rebut: 25 de març del 2020

Acceptat: 1 de juliol del 2020

\section{Resum}

Es presenta una estratègia didàctica basada en el misteri per a engrescar l'alumnat i augmentar la implicació i la motivació. Amb un enfocament constructivista, col-laboratiu i amb trets competitius i de gamificació, es treballen la redacció i l'exposició oral d'un text inventat pels estudiants.

\section{Paraules clau}

activitat, misteri, expressió oral, expressió escita

\section{Introducció}

A l'hora de plantejar als alumnes de secundària activitats per a treballar les expressions oral i escrita, molt sovint les rebutgen al moment perquè són aspectes freqüentment percebuts com a tediosos i poc motivadors. Tradicionalment, aquestes activitats han consistit a oferir-los un tema general o aspecte a tractar i demanar-los tota mena de composicions, com redaccions, biografies, exposicions orals o narracions. En aquest sentit, és senzill identificar-ne diversos inconvenients. Per exemple, els temes normalment són massa generals i en poques ocasions els desperten l'interès. També és molt habitual que no se'ls estimulin adequadament la imaginació i la creativitat, i no sàpiguen ben bé què escriure, ni com desenvolupar-ho. En definitiva, són activitats que els agradaria evitar perquè, abans de començar, ja pensen que no en fruiran, i que seran forçats a passar una estona dolenta tot pensant paraules, expressions o idees que mai no els arribaran a causa d'una ment adormida i poc motivada per la manca d'atractiu de l'activitat.

Per això, és natural que part de l'esforç en la investigació sobre la docència de llengües se centre en el desenvolupament d'activitats i estratègies didàctiques innovadores que proven d'eliminar aquests inconvenients (Canals, 2016). En aquest article s'exposa una estratègia diferent que cerca despertar l'interès i la implicació dels alumnes des del primer moment, per a evitar aquest tipus de situacions. Aquesta fita s'assoleix mitjançant un element de provada 
eficàcia a l'hora d'engrescar els adolescents: el misteri. En lloc de presentar-los un tema i un format determinat per a les seves composicions, sense cap contextualització ni connexió amb els seus interessos potencials, se'ls presentarà una situació estranya i oberta, la qual hauran de resoldre i exposar, tot desenvolupant el format adient, la solució, desenllaç o situació finals que se'ls acudeixi.

\section{Objectius}

L'objectiu del present escrit és demostrar el potencial que té l'element misteriós per a la docència de l'expressió oral i escrita. D'aquesta manera, les activitats descrites proven de generar un ambient de misteri que desperti la curiositat de l'alumnat per tal de facilitar un aprenentatge actiu i significatiu. L'objectiu principal de les activitats, per tant, esdevé engrescar l'alumnat per a aconseguir alts índexs d'implicació o proactivitat. Aquesta circumstància permet que el procés d'ensenyament-aprenentatge gaudeixi dels avantatges característics de l'aprenentatge actiu, contextualitzat i basat en la motivació (Lázaro, 2006), en tant que els alumnes, amb aquest rol de protagonistes principals del seu aprenentatge, mantindran la ment desperta, $\mathrm{i}$ tindran una actitud favorable al desenvolupament dels nous coneixements i l'adquisició dels nous conceptes. Quant als objectius d'aprenentatge, la proposta cerca treballar l'expressió escrita i oral especialment en el context de l'argumentació. S'hi inclou l'ús correcte dels connectors, la coherència i la cohesió textual, l'exposició oral i el treball col-laboratiu.

\section{Descripció de l'activitat}

Aquest treball descriu una activitat d'aprenentatge de caire constructivista i col-lectiva, amb un enfocament inspirat en la gamificació i amb trets competitius. Està enfocada a alumnes que no tenen el català com a llengua nativa, tot i que és extensible a aquells que sí que la hi tenen. Efectivament, l'aprenentatge de llengües és una tasca cognitivament complicada i que sovint desperta la desmotivació en els estudiants a causa de l'alt grau d'esforç que demana. En aquest sentit, nombrosos treballs han demostrat els beneficis didàctics i formatius de l'aplicació de teories constructivistes amb metodologies lúdiques, amb resultats força positius quant a la motivació, actitud i assoliment dels objectius d'aprenentatge (York i deHaan, 2018). A continuació es desenvolupen les diferents fases que conformen l'activitat.

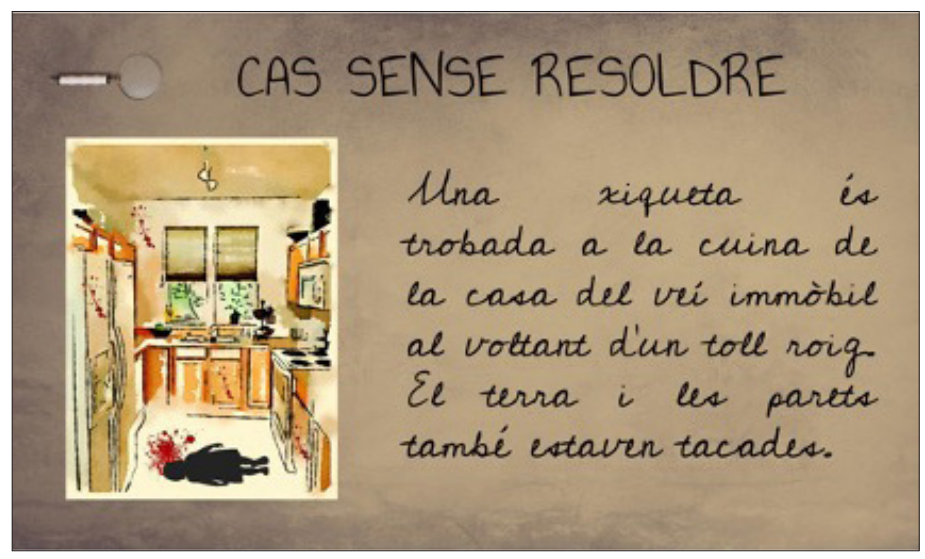

Fig 1. Exemple de presentació de l'activitat

\section{Primera fase: presentació i creació d'expectativa}

Per a realitzar l'activitat, primerament, es presenta el context als alumnes: des d'aquest moment són detectius i hauran d'endevinar què va passar abans d'arribar a la situació presentada. Es tracta d'una història policíaca sense resoldre, en què s'ha comès un determinat crim o hi ha una situació estranya. Se'ls exposa el cas mitjançant un text descriptiu i alguna imatge (Fig 1). Com que treballen per a la Unitat de Criminologia i Delinqüència de la policia judi- 
cial hauran de demostrar que saben treballar en equip. D'aquesta manera, s'organitzaran en grups reduïts, de 3 o 4 membres, per poder investigar de manera més minuciosa. És la seva obligació resoldre el cas, redactar l'informe definitiu i presentar-lo a la fiscalia. La correcció lingüística, tant oral com escrita, serà determinant perquè els fiscals accepten la resolució del cas. Al final del procés, només una resolució serà acceptada, aquella que s'apropi més a la solució real.

\section{Segona fase: interrogatori i recopilació de dades}

Seguidament es durà a terme l'interrogatori per tal d'adquirir la informació base amb què hauran d'elaborar l'informe. Per torns, el portaveu de cada grup haurà de preguntar a l'informador - la figura docent, qui coneix la solució ${ }^{1}$ - qüestions relacionades amb el cas. Aquest personatge només podrà donar una de les següents respostes possibles: «sí», «no»o "pregunta irrellevant». Les preguntes es faran de manera privada, i un grup no podrà conèixer les dels altres. El portaveu serà triat pel grup en cada torn i haurà de ser un membre diferent en cada iteració. El nombre total de torns es designarà en funció de la disponibilitat temporal i els requeriments de l'activitat. És en aquest moment quan l'enginy i l'astúcia faran que els alumnes siguin capaços de crear la seva pròpia història gràcies a les pistes que han sabut detectar. D'aquesta manera, és recomanable que els participants vagin desenvolupant un petit esbós de la seva resolució de manera continuada, a mesura que avança l'interrogatori.

\section{Tercera fase: elaboració i presentació dels productes finals, $i$ tria dels guanyadors}

Finalment, cada grup elaborarà el seu informe amb les dades que ha obtingut. Haurà d'inventar-se les que manquen i enllaçar-ho tot de manera lògica. Els informes seran lliurats al fiscal -el docent- i a continuació es faran les defenses, en què tots els integrants de cada grup hauran d'exposar la seva resolució del cas a la resta de companys. A l'acabar, el fiscal triarà la possible defensa guanyadora atenent a la similitud amb la solució real. En aquest punt, el docent llegirà l'informe corresponent i en comprovarà la correcció lingüística. Si és correcte, autoritzarà la finalització del cas i el grup guanyarà l'activitat. Si no ho és, triarà una nova possible defensa guanyadora i tornarà a comprovar l'informe corresponent, fins a trobar un grup guanyador. Aquest caràcter competitiu és una bona eina per a augmentar la implicació dels alumnes i el desig d'escriure i expressar-se correctament.

\section{Conclusions}

La implementació de les activitats exposades va donar com a resultat un assoliment satisfactori dels objectius de l'activitat i d'aprenentatge plantejats. L'observació va confirmar des del començament un augment de la motivació i de la implicació dels alumnes, amb una actitud participativa i proactiva. Els alumnes van voler participar en tots els aspectes de l'activitat, i s'hi va produir un ambient de treball agradable. Com a aspecte a destacar, cal remarcar la creativitat observada en les situacions proposades, però també és important fer menció especial a l'inusual alt grau de correcció dels textos presentats i de les exposicions finals. En aquest sentit, va ser molt positiva l'actitud de recerca i debat lingüístic que va sorgir entre l'alumnat amb la intenció de fer una activitat correcta i poder presentar-la adequadament. Aquesta motivació per donar a conèixer als companys les situacions proposades també va ajudar-los a superar l'habitual por de parlar en públic, un aspecte força difícil de millorar en alumnes de parla no nativa (von Kogerer, 2016).

En definitiva, s'ha provat com la inclusió de l'element misteriós i lúdic a l'hora de proposar els temes per a les composicions augmenta favorablement els nivells de motivació, implicació i

1 Per a l'exemple de la Figura 1, la solució proposada descriu com la xiqueta, coneixedora dels excel-lents espaguetis amb tomaca que sovint prepara el veí, es va colar a la seva cuina, va menjar-ne tants que va perdre el coneixement, va caure a terra amb els espaguetis i va tacar-ho tot de tomaca. 
aprenentatge actiu dels estudiants, i permet aconseguir resultats didàctics satisfactoris. Perquè açò siga possible, cal que la temàtica de l'activitat siga d'interès per a l'alumnat i els desperti les ganes de participar-hi. Un aspecte a considerar és el component competitiu, el qual ha d'estar gestionat de manera adequada. Un enfocament massa centrat a trobar la proposta guanyadora podria fer que es perdés el focus de l'activitat i no s'assoliren els objectius. Per últim, una altra possible opció per a millorar l'activitat seria incloure insígnies de diferents tipus (l'informe més creatiu, més divertit, millor argumentat, millor exposat, millor escrit, etc.) per facilitar la cohesió del grup i potenciar una mica més la motivació.

\section{Referències}

Canals, M. (2016). En context: expressió oral i escrita. Articles: Revista de didàctica de la llengua $i$ de la literatura, 71, 75-77.

Lázaro, P. (2006). L'aprenentatge actiu com a estratègia didàctica en una matèria teòrica. A III Jornada d'Innovació Docent 2006.

von Kogerer, S. (2016). Four teachers' thoughts about pupils' speaking anxiety in the ESL classroom. (Monogràfic. Universitat de Malmö). Recuperat de https://muep.mau.se/handle/2043/20139.

York, J. i de Haan, J. W. (2018). A constructivist approach to game-based language learning: Student perceptions in a beginner-level EFL context. International Journal of Game-Based Learning (IJGBL), 8(1), 19-40. 